https://doi.org/10.31470/2706-7904-2020-15-212-216

\title{
ЕКОНОМІЧНИЙ ДИСКУРС: ТЕОРЕТИЧНЕ ОБГРУНТУВАННЯ ПСИХОЛІНГВІСТИЧНИХ АСПЕКТІВ
}

\author{
Economic Discourse: Theoretical Substantiation of \\ Psycholinguistic Aspects
}

\author{
Nataliya Savelyuk \\ DSc. in Psychology, Associate Professor \\ Ternopil Volodymyr Hnatiuk National Pedagogical University (Ukraine) \\ nsavelyuk@ukr.net \\ https://orcid.org/0000-0001-5246-9677
}

\begin{abstract}
Economic discourse is one of the main types of institutional discourse, which is closely correlated with political discourse. The main non-economic vectors of his research are mainly linguistically oriented, while psychological, psycholinguistic relevant research in Ukraine is still not widely published. The theses highlight and briefly analyze three basic aspects of the theoretical consideration of economic discourse from the standpoint of modern psychology: cognitive, affective and conative. The cognitive function is performed primarily by metaphors, which contribute to a deeper knowledge and understanding of complex economic facts and phenomena. Emotional attitude to these phenomena is formed through the expressiveness of economic discourse. At times, it manipulates public opinion and the economic situation in general, as it is often used in the interests of the ruling elites.
\end{abstract}

Key words: economic discourse, psycholinguistics, metaphor, expressiveness, manipulation.

\section{Вступ \\ Introduction}

В умовах пандемії економічні проблеми України закономірно поглибилися та загострилися. Й одна з очевидних причин цього - недостатня економічна освіченість переважної частини нашого населення. Повноцінний економічний дискурс досі залишається прерогативою порівняно невеликої спільноти професіоналів, у той час як більшість послуговується лише його фрагментами або ерзацами. Як наслідок, українцями дуже часто маніпулюють не лише політично та геополітично, а й 
економічно. А тому вивчення специфіки економічного дискурсу, в тому числі його психолінгвістичних особливостей, - доволі актуальна та значуща дослідницька мета.

\section{Методи та методики дослідження}

Methods and Techniques of the Research

Дослідження має теоретичний та попередній (науково розвідувальний) характер. А тому в ньому використовуються, насамперед, теоретичний аналіз та синтез, мисленнєве узагальнення.

\section{Результати}

\section{Results}

Як зазначає Н.А. Ковальська, «наявність окремого соціального інституту, учасників, відповідної мети, тематики, способів спілкування, а також інших мовних та позамовних факторів дають підстави для виділення окремого інституційного типу дискурсу - економічного». Вчена розуміє економічний дискурс як «усне чи писемне мовленнєве відтворення комунікації осіб у сфері економіки», а також як фіксування певних моментів економічного буття (Ковальська, 2013: 196). Вважаємо, що така дефініція $є$ лише частково правильною, оскільки будь-який дискурс $є$ не тільки мовленнєвим, а й немовленнєвим відтворенням і творенням певних реалій буття.

Будь-який тип дискурсу є полісистемним і неоднорідним мовленнєвим явищем. Зокрема, У.Д. Перегінчук виокремлює наступні жанри економічного дискурсу: економіка підприємства, економіка промисловості, економічна статистика, основи маркетингу, бухгалтерський облік, менеджмент, гроші та кредит, міжнародна економіка, регіональна економіка, торгівля, фінанси. Усі вони поєднані між собою спільним лексико-семантичним полем концепту «економіка» (Перегінчук, 2012: 114).

Звернімося до «Сучасного тлумачного словника української мови», який пропонує три основні дефініції «економіки»: (1) сукупність суспільно-виробничих відносин; (2) господарче життя, стан господарства (країни, району); (3) структура i фінансово-матеріальний стан якої-небудь галузі господарської діяльності (Бусел, 2005: 339). Отже, асоціативне поле осмислення відповідного концепту формують, насамперед, такі поняття як «виробництво», «господарство», «фінанси», а також більш глобальні категорії «матеріальне буття», «суспільство», «діяльність» і т. п. Усі вони так чи інакше торкаються життєдіяльності та життєтворчості будь-якої людини.

С.М. Рибачок зазначає, що економічному дискурсу властиві емоційність та експресія, експліцитність і компресія, стереотипність і практична спрямованість. На 
відміну від політичного дискурсу, на думку вченої, дискурс економічний меншою мірою задіює цінність солідарності, а більшою мірою стимулює індивідуалізм. Характерною його рисою $є$ метафоричність, пов'язана 3 потребою пояснення та усвідомлення економічних явищ, а також із підтримкою певних соціальних уявлень населення (Рибачок, 2013: 316).

Для прикладу, О.А. Ільченко розглядає метафоричні словосполучення в економічній мові ЗМІ початку нашого століття. Проаналізувавши понад 2000 таких словосполучень у матеріалах друкованих, телевізійних та електронних 3МI, авторка дослідження розподіляє метафоричні звороти на дві великі групи: експліцитно оцінні («фінансова пастка», «фінансовий зашморг» та ін.) й імпліцитно оцінні («прозорий аукціон», «імплантація чужого» та ін.). Констатується, що в цьому дискурсі нерідко також використовуються елементи медичного («гостра бюджетна недостатність», «бензинова лихоманка» й ін.), військового («горілчані війни», «антиінфляційна атака») та аграрного («надої з держави», «хабарі землею» тощо) дискурсів (Ільченко, 2012).

В українській науці дуже мало власне психологічних досліджень економічного дискурсу. Аналізуючи ті з них, які мають хоча б елементи психологічного аналізу, та враховуючи системний поділ психіки на ії основні функції, виокремлюємо три базові аспекти теоретичного психолінгвістичного розгляду відповідного виду дискурсу: когнітивний, афективний та конативний.

I саме метафори виконують, як вище дотично зазначалося, в першу чергу інтерпретативну функцію, тобто сприяють глибшому пізнанню й усвідомленню доволі складних економічних фактів та явищ. Зокрема, на прикладах аналізу німецького економічного дискурсу Г.О. Строганова здійснює когнітивно орієнтовану класифікацію метафор на орієнтаційні (або просторові), онтологічні та структурні. Причому вживання двох перших типів (для прикладу, «економіка - це вертикальний рух» або «гроші - це рідина») сприяє кращому розумінню різних економічних процесів, натомість останній із перелічених типів («економіка - це гра» й ін.) слугує також формуванню певного ставлення до певних конкретних фактів та явищ (Строганова, 2011).

Ставлення до певних явищ з різними його емоційними відтінками формується через експресивність дискурсу. Н.А. Ковальська, зокрема, розглядає окличні речення в економічному дискурсі «як вищий прояв емоційної експресії». Учена доводить, що в межах українського економічного дискурсу окличні речення $\epsilon$ особливим комунікативним типом із самостійною цільовою установкою, пов'язаною 3 намірами автора тексту виразити свій психологічний стан, надати й передати певну емоційну оцінку фактам, а також експресивно вплинути на свого потенційного співбесідника (Ковальська, 2015). 
Натомість С.М. Рибачок розглядає економічний дискурс як засіб маніпулювання. Авторка слушно зазначає, що цей тип дискурсу не тільки надає інформацію та пояснює певні економічні події, а і впливає на суспільну думку та економічну ситуацію у цілому, причому часто в інтересах правлячих еліт. Інакше кажучи, економічний дискурс, що тісно пов'язаний із дискурсом політичним, належить до сфери та засобів соціального впливу, забезпечуючи фінансовоекономічні інтереси певних суспільних спільнот (Рибачок, 2015). Назагал усі три вище згадані функції - когнітивна, афективна і конативна, як відомо, тісно корелюють між собою, а тому практично будь-який метафоричний зворот у рамках дискурсу має багатоаспектний психологічний вплив.

\section{Висновки \\ Conclusions}

Отже, економічний дискурс - один з основних типів інституційного дискурсу, що тісно корелює з політичним дискурсом. Основні позаекономічні вектори його дослідження наразі $\epsilon$ переважно лінгвістично орієнтованими, натомість психологічні та власне психолінгвістичні відповідні розвідки в Україні досі широко не оприлюднені. Отже, перспективи подальших досліджень убачаємо у використанні методів і методик сучасної психолінгвістики для дослідження, зокрема, метафоричних зворотів українського економічного дискурсу та їх впливу на свідомість і поведінку.

\section{Література References}

Бусел, В.Т. (Ред.). (2005). Великий тлумачний словник сучасної украӥнської мови (з дод. i допов.). Київ; Ірпінь: ВТФ «Перун».

Ільченко, О.А. (2012). Метафоричні словосполучення економічного дискурсу в мові ЗМІ XXI ст.: аксіологічний аспект. Наукові записки Національного університету «Острозька академія». Сер.: Філологічна, 29, 75-77.

Ковальська, Н.А. (2015). Окличні речення як вищий прояв емоційної експресії в українському економічному дискурсі. Філологічні студіï. Науковий вісник Криворізького державного педагогічного університету, 13, 280-286.

Ковальська, Н.А. (2013). Релевантність економічного дискурсу. Наукові записки Наиіонального університету «Острозька академія». Серія: Філологічна, 38, 193-196.

Перегінчук, У.Д. (2012). Жанрова класифікація економічного дискурсу. Наукові записки Наиіонального університету «Острозька академія». Серія: Філологічна, 23, 111-114. 
Psycholinguistics in a Modern World - 2020. Proceedings of the 15th International Scientific and Practical Conference (Pereiaslav-Khmelnytskyi, 22-23 October, 2020)

Рибачок, С.М. (2015). Економічний дискурс як засіб маніпуляції. Гуманітарна освіта $y$ технічних вищих начальних закладах, 31, 105-116.

Рибачок, С.М. (2013). Економічний дискурс як об'єкт дискурс-аналізу. Мовні і концептуальні картини світу, 43(3), 311-317.

Строганова, Г.О. (2011). Когнітивна класифікація метафор у німецькому економічному дискурсі. Гуманітарна освіта у технічних вищих навчальних закладах, 23, 193-201. 